\title{
"Walls of Freedom": Street Art and Structural Violence in the Global City
}

\author{
Dominic Davies \\ English Faculty, University of Oxford, UK. Email: dominic.davies@ell.ox.ac.uk
}

Received May 11, 2017; Revised July 07, 2017; Accepted July 07, 2017; Published August o6, 2017.

\begin{abstract}
This article argues that contemporary street art (or graffiti) uses a unique set of resistant techniques to foreground the contours and shapes of different kinds of structural violence inscribed into, and perpetuated by, the infrastructural layouts of the twenty-first century's increasingly global cities. Graffiti can resist structural violence as it is shaped and exacerbated by - even embedded within - the physical walls of city spaces, ricocheting off into alternative and on occasion more democratic modes of urban habitation. Through a discussion of examples from urban spaces as diverse as revolutionary Cairo, divided East Jerusalem and the West Bank in Palestine, and South African townships and gentrifying East London, the article shows that street art can transform the violent infrastructural strategies of oppressive state governance into a canvas that articulates calls for democratic and political freedom.
\end{abstract}

Keywords: graffiti, street art, structural violence, the global city, urban social formations, cultural resistance, visual culture

\section{Introduction: Breaking the Law/Wall}

Contemporary street art, or graffiti, has come increasingly to be used by practitioners to foreground the structural and state violence that is inscribed into, and perpetuated by, the infrastructural layouts the twenty-first century's increasingly global cities, most visibly in the recent proliferation of wall construction. For Maria Daskalaki and Oli Mould, subcultural practices such as graffiti writing and drawing are more helpfully understood as Urban Social Formations (USFs). These USFs function not by disregarding and operating 'outside' of top-down, governmental urban planning and state infrastructure-rather, they engage 'with the urban topography in new and innovative ways' so as to extend 'the functionality of the planners' original intentions' $(2013,1)$. More complexly, USFs such as graffiti subculture are, Daskalaki and Mould continue, 'inherently rhizomatic and, as such, are significant agents of creative urban collaboration and transformations' (7); that is, graffiti can resist structural violence as it is shaped and exacerbated by-even embedded within - the physical walls of city spaces, ricocheting off into alternative and on occasion more democratic modes of urban habitation. Street art transforms the violent infrastructural strategies of oppressive state governance into a canvas that articulates calls for freedom from this violence. This article will explore these processes through a discussion of specific examples from increasingly 'global' cities, which, according to urban theorist Saskia Sassen, allow 'non-state actors [to] enter and gain visibility in international fora or global

(c) AesthetixMS 2016. This Open Access article is published under a Creative Commons Attribution Non-Commercial 4.0 International License (http://creativecommons.org/licenses/by-nc/4.o/), which permits non-commercial re-use, distribution, and reproduction in any medium, provided the original work is properly cited. For citation use the DOI. For commercial re-use, please contact editor@rupkatha.com. 
politics as individuals and as collectivities, emerging from the invisibility of aggregate membership in a nation-state exclusively represented by the sovereign' $(2004,649)$.

The construction of walls has proliferated in recent years in response to these destabilising global dynamics. As Wendy Brown observes, 'new nation-state walls are part of an ad hoc global landscape of flows and barriers both inside nation-states and in the surrounding postnational constellations, flows and barriers that divide richer from poorer parts of the globe' (2010, 24). However, as she continues, 'one irony of late modern walling' is that these physical infrastructures, though designed to 'enforce an inside/outside distinction' in fact serve to highlight 'a complex of eroding lines between the police and the military, subject and patria, vigilante and state, law and lawlessness' (25). This article shows that the proliferation of these physical surfaces not only betray these underlying insecurities and the structural violence that motivates their instantiation. They also offer canvases on which the subcultural political practice of street art and graffiti can gain a global visuality that further highlights these injustices in order to communicate alternative political subjectivities.

Walls are designed to function 'not only as physical barriers but also as devices to exclude both the visual and the aural' (Weizman 2012, 209). Graffiti subverts this effort, transforming them into platforms for articulating alternative visions of increasingly democratised urban spaces through their imagistic critique of physical infrastructural violence. If the almost 'palindromic linguistic structure of law/wall' reveals the extent to which 'built and legal fabric' are interrelated, the 'un-walling of the wall', argues architect Eyal Weizman, 'becomes the undoing of the law' (210). As a physical assault on the wall that is, not always but often, an illegal act, graffiti bears a 'spontaneous, rupturing quality' (Lennon 2014, 241) that, like rhizomatic USFs more generally, 'open up possibility and new fields of urban engagement' (Daskalaki and Mould 2013, 2). By breaking the law, graffiti also breaks - or at least resists - the state hegemony that the wall both symbolically signifies and materially endeavours to implement. In one further critical turn, graffiti can be said to transform these hegemonic walls so that, as Judith Butler has remarked of physical protest in urban space more generally, 'those material environments [become] part of the action, and they themselves act when they become the support for action' (2011).

Sassen, in her more recent response to the protests that exploded across the Arab world and elsewhere in 2011, emphasises the new centrality of what she calls 'the Global Street' to the configuration of the global city, arguing that '[t]oday's political practices [...] have to do with the production of "presence" by those without power and with a politics that claims rights to the city and to the country rather than protection of property' $(2014,574)$. These political practices, often comprised of what Manuel Castells has called 'networked social movements' that link up 'cyberspace and urban space', have laid claim to the central squares of global cities, rejecting formal and authoritarian politics and 'relying on the Internet and local assemblies for collective debate and decision-making' (2012, 3-4). Graffiti intervenes into this interface between urban and cyber space in productive ways. In fact, 'far from insisting on the simplistic division between socalled "real" spaces of urban squares and the "unreal" spaces of the ascendant digital media landscape, graffiti articulates a multi-layered practice of image politics that puts screen cultures into complex negotiation and self-reflexive re-appropriation with those of the street' (Elias 2014, 89). Specifically discussing the case of graffiti in revolutionary Egypt, John Lennon has shown how graffiti turns 'city space' from a 'physical location' into a 'global entity', flinging images daubed onto concrete walls into a global public and media sphere 'at the speed of a Twitter post' (2014, 244-245). Nevertheless, a debate that recurs throughout the numerous opinion pieces and accounts included in a recent book-length collection, Walls of Freedom: Street Art of the Egyptian 
Revolution (the proclamatory first clause of which is borrowed by this article), hinges on this relationship between the online space of the Internet and the physical space of the street. For participants in the Egyptian revolution, the general feeling is that although the Internet plays a significant role in 'transcending the physical and political barriers to image dissemination and information exchange, the most important struggles will undoubtedly be waged on the streets and in the squares of Egyptian streets' (Elias 2014, 91).

For Castells, the 18 Day Egyptian Revolution that took place in January 2011 is emblematic of these revolutionary movements, and it is indicative that graffiti and street art has since exploded in Tahrir Square and other parts of Cairo, as several news outlets and critics have documented (see Abaza 2013; Lennon 2014), as well as two book-length projects, Revolution Graffiti: Street Art of the New Egypt (2013) and Walls of Freedom (2014). A symptom 'of the creative energy the revolution had released across the country' (Souief 2014, 5), graffiti subculture has exploited the loosening of state hegemony, especially as it manifests through the alteration-most notably, the securitisation and militarisation-of Cairo's physical infrastructures (see Kingsley, 2013). If the walls constructed to reinstate state power and limit the movements of protests have proliferated across the city, this infrastructural effort actually reveals, as Brown would argue, the precarity of that power. Graffiti seizes on this precarity as it manifests in the law/wall infrastructure, turning it into a canvas that levers open the oppressive violence ingrained within its physical materiality. This article therefore concludes with a discussion of one particular example of resistant street art that challenges the structural violence of walling in post-revolutionary Cairo. However, it begins with a nuancing of the notion of graffiti as a form of cultural resistance, turning to examples from other geographical instances of militarised or securitised urban walling to show that street art can operate as resistance on a more subtle, day-to-day level, before addressing the use of graffiti in Egypt's more overtly politicised city spaces.

\section{Graffiti as Resistant Political Practice and Urban Social Formation}

The consideration of graffiti culture as a resistant political practice has been a subject of much academic debate in recent years, raising questions about the very notion of resistance itself. Jeff Ferrell, for example, argues that 'activities like graffiti writing not only shape resistance to existing arrangements but construct alternative arrangements as well', concluding that 'scholars must avoid defining resistance so narrowly or rigidly that only those activities that fit prearranged categories or larger political agendas count as resistance' (1995, 74-5). This resonates with Howard Caygill's careful avoidance of 'the conceptual unification of "a Resistance", highlighting the 'resistance of resistance to analysis' $(2013,7)$. To define resistance outright is to limit it, rendering it 'predictable, open to control and thus lowering its resistance' (6). With this in mind, the claims made by this article for graffiti as a form of cultural resistance are qualified by the acknowledgement that every geohistorical location of its emergence will be subject to a specific set of criteria and will target different forms of power, all of which will be contingent on the circumstances of its production.

Nevertheless, an agile conception of resistance is encompassed by the diverse kinds of cultural work included under the labels 'street art' and 'graffiti'. Ranging from base criminal vandalisms to more self-consciously 'artistic' forms of intervention, graffiti clearly recognises 'multiple configurations of authority and embrace[s] various styles of resistance to them' (Ferrell 1995, 76). Simply by appearing on private property, for example, graffiti 'reclaims public space for at least some of those systematically excluded from it' (79), disrupting the constellations of legal, 
political and infrastructural networks of authority, especially as these materialise in the physical walls that graffiti seizes as its canvas. Graffiti is a simple and direct way through which artists and activists mark their political subjectivity, and announce their integration, or lack thereof, into a particular city space. Ultimately intended to communicate a message, whether explicitly politicised or not, street art also creates 'a place of public engagement that invites collaboration in its production and in its reading' (Frederick 2009, 211), fostering solidarities against the discriminatory and often violent effects of urban walling.

Graffiti is therefore adept at transgressing the increasingly divided, segregationist and militarised infrastructures of the contemporary global city-that is, of the 'new military urbanism' that positions 'war as the dominant metaphor in describing the perpetual and boundless condition of urban societies' (Graham 2011, xiii-xv). Outside of the explicitly politicised practice of street art in revolutionary Cairo, graffiti functions as an urban social formation that is selfconstituted and internally coherent, with practitioners writing as much for one another as they do for state authority or an urban public. Artistic interventions onto the walls of global cities exhibit both a disregard for, but also engagement with, the structural violence of the global city, especially as it is ingrained into its physical infrastructure. It is this simultaneity of engagement and defiance that allows graffiti to actively reshape the way those infrastructures are understood, with rhizomatic ramifications as the images and words are interpreted in multiple and often contested ways by different publics and polities. Graffiti is not always intended as a direct political intervention. Nor is it merely 'an act of spite or malice or a "for the hell of it" crime which angry working-class kids use to attack the middle classes at their most vulnerable'; as Nancy Macdonald argues, street artists 'conform to their own meaningful guidelines and structure', and seek their 'own audience and [...] own agenda' (2002: 92-3). For some critics, '[a]lthough it may be simpler to separate graffiti into political and non-political demarcations', as for conceptions of resistance more generally 'it behooves us to panoramically assemble our understanding of graffiti' into these two groupings - the line between "'political" and "nonpolitical” writing is certainly ambiguous', if not 'irrelevant' (Lennon 2014, 248-249). After all, graffiti subculture's disregard for political authority or state-sanctioned violence might be configured in and of itself as a form of resistance.

Nevertheless, Guillaume Marche argues that 'protest graffiti' usually contains 'an explicit political referent' (2012, 79-80). For Marche, protest graffiti functions as what James Scott would call an 'infrapolitical' practice-it excavates the 'unobtrusive realm of political struggle' to reveal the deeper 'cultural and structural underpinning of the more visible political action' (Scott 1990: 183-4). By exposing these deeper contours, Marche argues that this infrapolitical dynamic of protest graffiti creates a set of 'complex virtual interactions between authors and viewers' that can insinuate 'an oppositional consciousness' into witnessing urban publics (Marche 2012, 80). Whilst such faith in the effectiveness of protest graffiti and other kinds of street art perhaps needs to be tempered, Marche is astute to emphasise that graffiti's impact is contingent on the walled space of the global city into which it intervenes-graffiti may make politically resistant claims, but it also 'perform[s] resistance to the excess of signification with which urban environments are saturated'; here, 'the medium is indeed the message' (82-83). Alternative urban social formations undercut, transgress and reject the 'law/wall' infrastructures of city spaces, conveying their resistance through an illegal (law) and physically vandalising (wall) art form. Ironically enough, state efforts to prohibit the practice and, as occurred repeatedly in Cairo, to 'abate' (paint over) these artistic productions, actually 'reinforces graffiti's resistant potential'; as Michelle Stewart and Chris Kortright observe, the oscillation between graffiti and 'abatement' reveals an ongoing antagonism 'over class, space and the right to private property' that is highly visible to the global city's average urban citizen $(2015,68)$. 


\section{Examples: The Writings on the Wall}

Since its inception in 2002, the Israeli 'separation barrier' in East Jerusalem has functioned as 'an instrument of partition' and 'an apparatus of observation and control', but also, Weizman demonstrates, as a 'powerful image within a media-economy of the conflict' (2012, 153, 171). Though Israel's segregationist infrastructural networks of roads, bridges and settlements proliferate throughout Jerusalem and the West Bank, the Wall has arguably come to be the symbolic pinnacle of the occupation for Israeli's and Palestinians alike. Graffiti artists, both amateur and professional, have seized upon this concrete canvas to re-cast the Palestinian side of the separation barrier as a documentation of protest and resistance to the Israeli occupation of the West Bank. As William Parry observes, '[t]he spray can hasn't forced Israel to stop building its highly controversial Wall, but in the skilled hands of a guerilla street artist like Banksy, it's a formidable weapon in the struggle for hearts, minds and justice' (2011, 9).

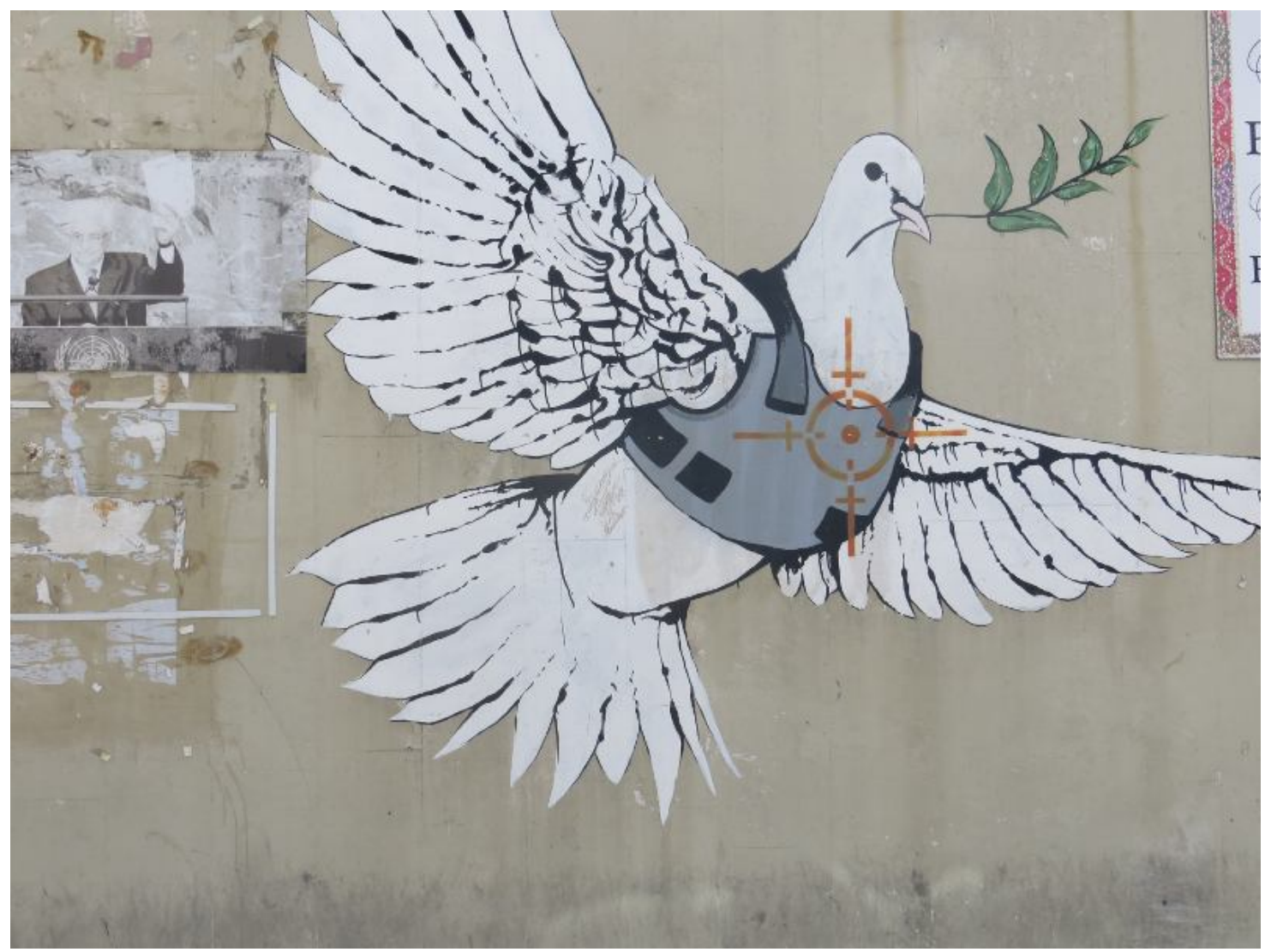

Fig.1: Banksy's ‘Armoured Dove of Peace’ on the side of a Palestinian house near to the separatino barrier.

This Palestinian protest graffiti engages a self-consciously cross-national politics, including 'quotations from [...] freedom fighters like Gandhi and Nelson Mandela [that] challenge the inhumanity of Israel as occupier and oppressor', alongside 'symbols central to Palestinian identity, denoting resistance, liberation, affinity to the land [...] and national unity' (Parry 2011, 10). Banksy's intervention into this local graffiti subculture in 2005 further launched it-and the violence to which it responded-onto a global stage. The content of Banksy's own artwork was outward looking: his image of a dove carrying a sprig of green leaf, whilst also adorned in a flak jacket and targeted by a red cross-hair, conveys Israel's transformation of a Christian holy site (it is located in Bethlehem) into a site of military occupation. The Christian symbol for peace is made to embody the continued militarisation and precarity of the Israeli occupation after the Second 
Intifada and the building of the Wall. By drawing on the Christian biblical text, rather than speaking to the majority Muslim communities that surround it, Banksy's dove orients the protest graffiti outwards, toward Britain and the US, raising a global awareness of, and solidarity against, Israel's increasingly segregationist infrastructural strategies. As would become the case for street art in Cairo's Tahrir Square and Mohamed Mahmoud Street, the resulting 'palimpsest of Arabic and English' creates 'a rhetoric of protest meant for dispersion past the city walls' (Lennon 2014, 244).

However, if the graffiti on the Israeli separation barrier is demonstrative of the transformation of segregationist walls into a canvas for protest, it is not unproblematic. Banksy recalls a conversation he had with a Palestinian man, who approached him as he was working:

Old Man: You paint the wall, you make it look beautiful.

Banksy: Thanks.

Old Man: We don't want it to be beautiful. We hate this wall, go home. (Parry 2011, 10).

The political effectiveness of Banksy's continuing interventions in the region remains contested. His artwork appeared in Gaza in 2014, daubed onto the desecrated infrastructure of the Strip's urban enclaves in an attempt to highlight the devastation caused by Israel's 'Operation Protective Edge' in the summer of 2014 (Chaderjian 2015). This graffiti, inscribed onto the destroyed walls of Palestinian homes rather than the solid concrete slabs of the separation barrier, highlights a different aspect of the ongoing ramifications of Israel's violent urban warfare that, since it came to a precarious conclusion at the end of August 2014, has fallen out of headlines in the global media. Yet more recently, in 2017 Banksy opened a 'Walled Off Hotel' in the West Bank, the rooms of which 'look out on to the concrete slabs of the wall' and which functions as a 'a hotel, museum, protest and gallery all in one' (Graham-Harrison 2017). Though celebrated by certain members of the international community, critics have argued that the hotel transforms the separation barrier into 'an exhibit [for] a very specific class of tourists who are able to enter the West Bank', resulting in an 'an audacious exploitation of Palestinian suffering that manages to negate it and market it as art' (Nassar 2017).

As Daskalaki and Mould observe of USFs more generally, the 'prohibition and illegalisation' of subcultural practices such as graffiti might attract urban 'outsiders', but they also invite 'marketing and advertising organisations, which take profit from these "rebellious" cultural images' $(2013,2)$. In this case, however, I would contend that Banksy's graffiti continues to draw attention to the plight of Palestinians, levering some forms of international support and gaining global attention for the protest graffiti of local Palestinians. Accusations that Banksy denies Palestinians 'the agency to speak of their own suffering' have some weight (Nassar 2017), but overlook the fact that Banksy works collaboratively with other artists (some local-his name might better be understood to refer to a collective as much as an individual), as well as the fact that Banksy's art is frequently surrounded-if not infringed upon-by the scrawls of Palestinian graffiti.

The work of British graffiti artist Ben Slow is similarly international, including pieces in the cities of London, Paris, Philadelphia and Johannesburg, and if it does not receive the same global attention as Banksy's street art this in fact serves to resist the possible commodification of both the subcultural form and its subversive content. Though not engaging in the conventional visual currency of graffiti 'writing' or 'tags', his images speak to a graffiti 'subculture' as much as they do to the general public. His striking images include huge, two or three metre depictions of the faces of iconic figures affiliated with radical political movements that have historically resisted forms of 
structural violence and urban segregation. By recording these histories on walled canvases, their resistant legacies are insinuated into the minds of his viewers and actively intervene into the contemporary urban landscape.

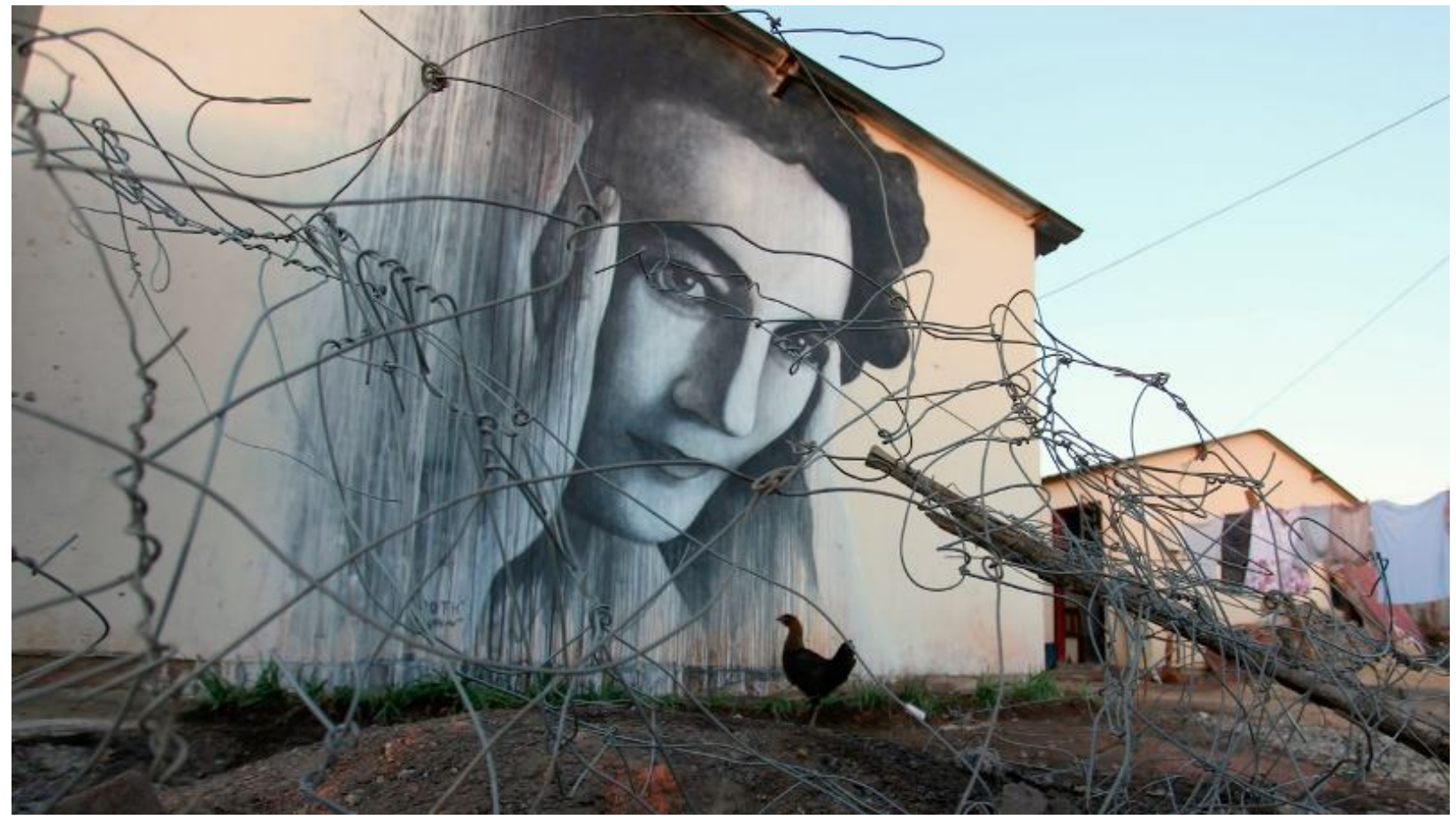

Fig.2: Slow's portrait of 'Ruth First' painted onto the side of a matchbox house in Soweto.

In October 2012, on the 3oth anniversary of the assassination by letter bomb of antiapartheid activist Ruth First in Mozambique, Slow began painting a four metre tall mural of her face onto the side of a matchbox house in Nomzamo Park, Orlando East in Soweto, Johannesburg. The choice of Soweto, with its strong ties to the anti-apartheid movement, is significant, and the piece was warmly received by the township's inhabitants and vocally celebrated by Gillian Slovo, Ruth First's daughter (Motumi 2012). By painting this image of a key anti-apartheid figure onto an infrastructural demarcation that is itself an emblematic residue of the apartheid state, Slow resurrects the politics of the past-namely, resistance to racial and economic inequality-and implicitly directs them at the ongoing structural violence that remains latent in the infrastructural walling of Johannesburg in the twenty-first century. Indeed, Nomzamo Park is surrounded by a set of dramatic infrastructural demarcations-the Orlando river system and its dams, Chris Hani Road, a railway line, the neighbouring Soweto Golf Estate-whilst itself remaining a predominantly underdeveloped informal settlement with high levels of ecoli and other pollutants in its water-system. Slow's depiction of First activates a memory of resistance to state violence and infrastructural neglect in the minds of the township's inhabitants, arguably reigniting a political consciousness that undercuts infrastructures-surveillance cameras, walls, barricades, gates, alarms, armoured vehicles, fortified entrances, intercom systems-[that] fragment the city' (Bremner 2010, 100). 


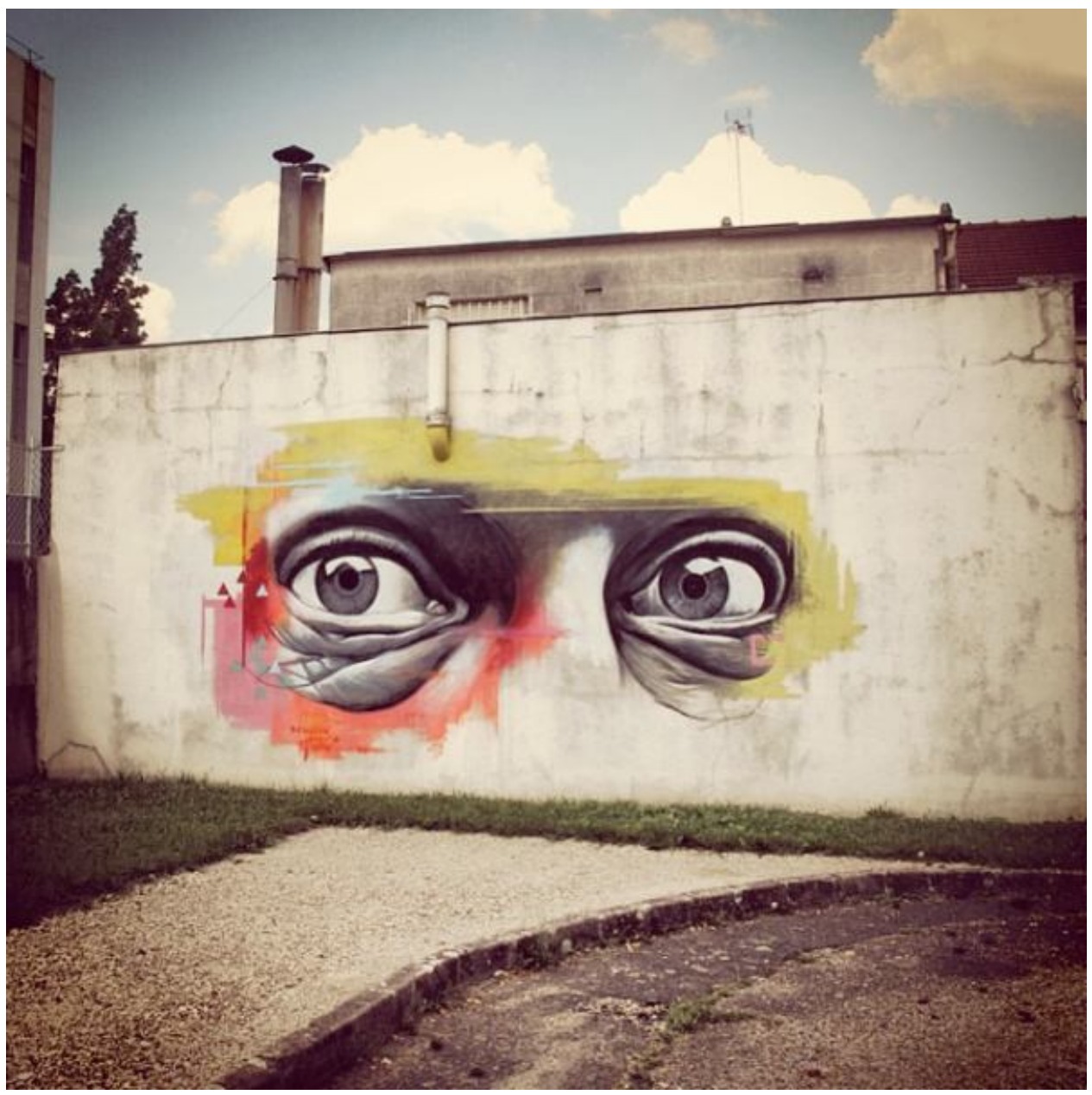

Fig.3: Slow's disembodied eyes on a wall in Vitry Sur Seine.

More recently, Slow has instead drawn sets of eyes that glare out of the walls on which they are painted. These accusatory gazes activate the idea that the walls themselves are invested with a certain agency, emphasising that the built environment is imbued with-if not an agent of - the sometimes violent legal infrastructure of the state. These penetrating gazes might even be read as a commentary on the spread of surveillance technologies throughout global cities, a theme commented on in much of Banksy's work. However, the title of one of these images, 'Vitry Sur Seine', which is located on a wall in a south eastern suburb of Paris of the same name, reveals a set of further political connotations that initiate a reflection on the practice of graffiti itself. Historically, a commune in Vitry Sur Seine practiced a cultural policy of producing and exhibiting art in public spaces, and there are hundreds of sculptures remaining in the area. Positioned amongst these pieces and named after the commune, Slow's intervention aligns the practice of graffiti writing itself with the subversive politics of communal activity and the occupation of urban space through an invocation the Paris Commune of 1871-which, as Kristin Ross documents at length, was 'a worker-led insurrection transformed the city of Paris into an autonomous Commune [that] set about improvising the free organisation of its social life according to principles of association and cooperation' $(2015,9)$. These communal activities are then replicated by the subculture's defining features: free access (graffiti art is 'public', open to all and-with some gentrified exceptions-not available for purchase) and transience (street art never lasts 
forever, and is often erased after a certain period, rejecting a culture of preservation and permanence).

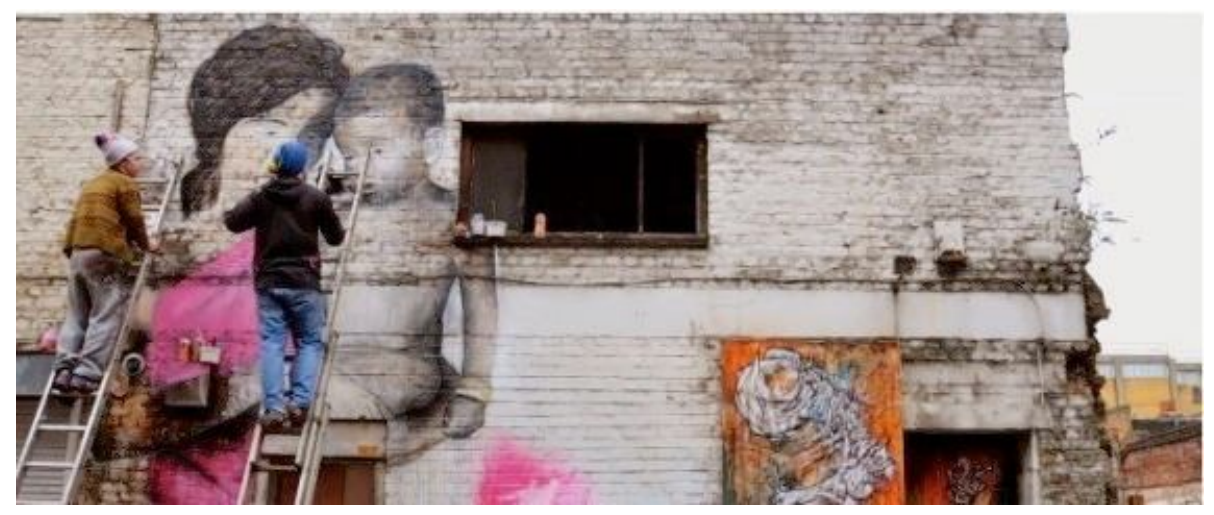

Fig.4: Slow and his collaborators work on a wall in London's Brick Lane.

Turning from one global city to another, and moving from solo-authored to collaboratively produced graffiti, in early 2011 Slow worked with Joe Deane and Joseph Loughborough to paint a striking image of an South Asian mother with her child onto a wall in Brick Lane in London. The child they depict is clearly malnourished, and the mother's position suggests her inability to provide for him. The ethnicity of the depicted pair denotes Brick Lane's immigrant community, whilst the theme of shelter invoked by the image comments on London's 'architecture of extreme capitalism' that, as Anna Minton observes, 'produces a divided landscape of privately owned, disconnected, high security, gated enclaves side by side with enclaves of poverty which remain untouched by the wealth around them' (2012, xii). Located on Hanbury Street just off Brick Lane, it is painted onto a decrepit, disintegrating wall that contrasts sharply with the glittering and continually encroaching developments of Canary Wharf just a few streets away. Situated in this way, the piece highlights the exacerbation of London's urban poverty and inequality by drawing attention to its unevenly developed infrastructural walling. The project was documented in a short film indicatively entitled 'Street Art Collides With Reality In London', which revealed that behind the dilapidated façade upon which the image appears is a building home to a group of Romanian workers who 'live with no running water' and are surrounded by uncollected 'trash' (Rahman 2015). Though it has since been removed, for a period the graffiti made visible the violence inflicted upon London's urban populations-many of whom are also its cheap and informal labour force-that otherwise remain concealed behind the global city's proliferating walls.

By way of concluding this overview of examples from various global urban contexts, I want finally to return to Cairo, where 'graffiti was one of many resistances that led to the abnegation of the presidency by Hosni Mubarak and the continued protests against SCAF [the Supreme Council of the Armed Forces]' (Lennon 2014, 239). Graffiti was especially crucial during the 18 Day revolution in January 2011. 'The wall', writes Ahmed Aboul Hassan, was the voice of the revolution, the cradle where Egyptian revolutionary identity was born, the place where it was nurtured' (2014, 134). Graffiti aside, Tahrir Square had for decades been a site of public and political protest, and had thus also been repeatedly reconfigured by an invasive governmental architecture of walling intentionally-and often violently-designed to break up such demonstrations. As Derek Gregory observes, over and over 'the site was fenced off and placed out of bounds, while state-directed urban planning worked in tandem with the Emergency Law, limiting demonstrations to choke off the public spaces in which the capillaries of political life could flourish' $(2013,239)$. If in 2011 this cyclical walling process was at last broken, the 
combination of local physical occupation and highly visual global coverage online played a fundamental role. As Gregory continues, 'social media and satellite television ensured that what took place (literally so) in Tahrir was relayed around the world', and yet crucially 'there remained something localised that could not be transported. Tweets took flight, but their senders did not' (243). Here we find graffiti at another crucial interface: not only residing between an irreverent disregard for walling infrastructure and a strategic re-appropriation of it, as already identified; but also between a local, physical presence in the city and the photogenic snapshot ready to circulate virally online, that latter of which lingers long after its physical eradication.

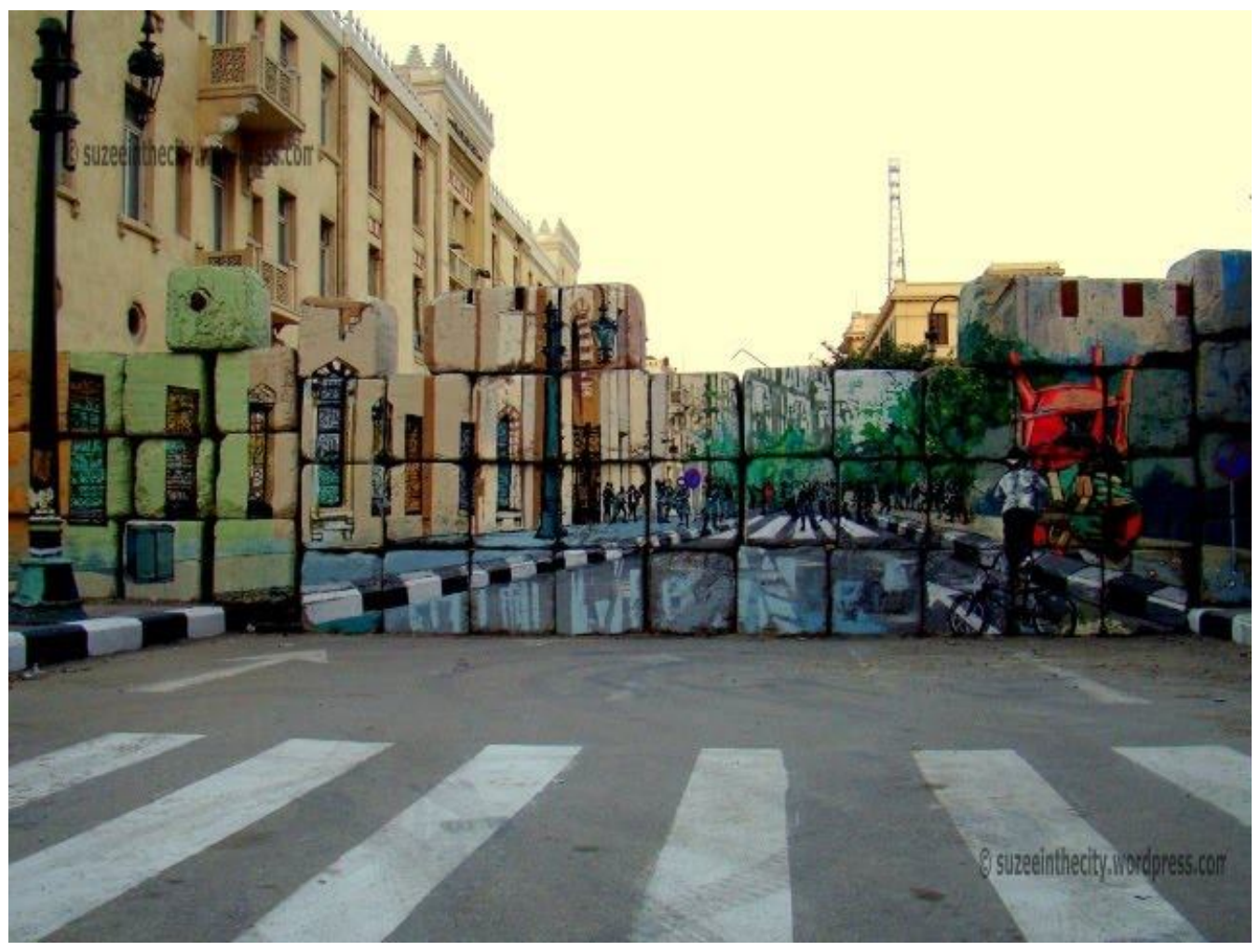

Fig.5: A repainted military wall on Sheikh Rihan Street in Downtown Cairo, 'meticulously designed and planned by a group of artists, including Ammar Abo-Bakr, Mohamed al-Moshir, Laila Maged and their collaborators. The result is an almost perfect extension of Sheikh Rihan Street' (Morayef 2012).

In the months following the deposition of Hosni Mubarak, SCAF attempted to shut down dissenting street protests, counteracting 'the revolutionaries by "zoning" and confining the protesters, segregating them in limited spaces of war' through 'the erection of multiple cement walls and the blocking of entire parallel streets with stone walls and military vehicles' - tactics that Morsi's Islamist and then el-Sisi's military governments have since continued (Abaza 2013, 127). If the 'walls were erected, supposedly as a temporary measure', they soon became a permanent fixture, stagnating 'the once-lively streets in their immediate vicinity' (Kingsley 2017). Nevertheless, as during the 18 Day Revolution, these new walls were swiftly reconfigured as canvases by activists and artists, who again used social media to organise their physical interventions into urban space (Abaza 2013, 128). Worthy of specific note is the 'No Walls Project', who set about painting 'a series of landscapes' in order to 'to re-open the blocked streets by making the walls invisible' (Dahsan 2012). Invoking some of Banksy's work on the separation barrier in the West Bank, these scenes functioned 'to pierce with illusory landscapes the segregating walls', whilst more informal graffiti made similar cross-national connections by 
accusing SCAF of imitating Israel's oppressive walling policies against the Palestinians (Abaza 2013, 128).

One particular space in Cairo has come to embody what Sassen identifies as the 'political practices' of 'the Global Street' $(2014,574)$. Mohammed Mahmud Street, one of the main arteries leading to Tahrir Square and the site where 'over 40 protesters were killed by police forces' in 2011, has come to be known as 'sharei' uyuun al-hurriyyah', or 'the Street of the Eyes of Freedom', functioning as an iconic space that pays tribute to the Egyptian revolution, whilst also documenting contemporary resistant activities as they continue to play out (Abaza 2013, 126, 128129). This poignant renaming of the street not only resonates with Slow's painting of accusatory eyes on walls in Paris and London. It further references the global community that graffiti, as both localised urban practice and internationally circulating visual culture, is calling into being. As Andy Merrifield observes, 'the Baudelairean "family of eyes" has gone truly global':

with the Internet [...] a global family of eyes has the potentiality to encounter itself as a family, as an emerging citizenry, as an affinity group that yearns to repossess what has been dispossessed. Their big saucer eyes now look on with indignation, in a citizens' agora currently making itself [...] there's not so much a world for the working class to win as a whole world for urban citizens to occupy, to reclaim and remake as their cité. $(2014,87)$

\section{Conclusion: Global Walls, Global Networks}

Though compromised, as for other USFs, by the occasional co-option of gentrifying market forces, the examples of street art examined in this article demonstrate an increased political engagement and effective resistant practice that is global in scope. By raising public awareness of structural forms of violence that otherwise remain latently inscribed into the walled infrastructure of contemporary urban environments, graffiti functions to give the global city's most marginalised populations a voice. Indeed, it is the global platform offered by the contemporary city which connects these local acts of creative resistance and alternative practice together, as they develop in interaction with and yet in refutation of the global city's violent urban infrastructures. If the global city functions as a 'denationalised platform for global capital', it also enables 'local, often resource-poor organisations and individuals [to] become part of global networks and struggles' (Sassen 2004, 649-650). This can be extended to understand the increasing efficacy of graffiti and street art as a mode of urban resistance, one that exploits processes of walling to create local interventions that affiliate themselves with wider global resistance movements, even as these originate in other walled spaces.

Global cities are undoubtedly becoming increasingly violent and unequal, and the locus of state power, discrimination and oppression more dispersed, pervasive and insidious. In recent years, walls have proved to be an evermore common infrastructural strategy for maintaining socioeconomic division and preventing the consolidation of public forums for protest and dissent. Nevertheless, even as these walls proliferate, the methods of resistance to these infrastructural manifestations of planned violence, enabled by USFs such as graffiti subcultures, are likewise proving ever more agile, versatile and creative, able to re-engineer a walled urban terrain, as David Harvey has argued, into 'a weapon in [their] political struggles' (Harvey 2012, 118). 


\section{References}

Abaza, Mona. 2013. 'Walls, Segregating Downtown Cairo and the Mohammed Mahmud Street Graffiti'. Theory, Culture E Society, Vol.30, No.1: 122-139.

Bremner, Lindsey. 2010. Writing the City Into Being: Essays On Johannesburg, 1998-200o. Johannesburg: Fourthwall Books.

Butler, Judith. September 2011. 'Bodies in Alliance and the Politics of the Street'. European Institute for Progressive Cultural Politics (EIPCP). Online Source: http://www.eipcp.net/transversal/1011/butler/en Accessed 11 May 2017.

Chaderjian, Paul. 2015. 'Banksy Goes to Gaza'. Al Jazeera. 1st March. www.aljazeera.com/news/2015/o3/banksy-gaza-15030116004377o.html.

Dahsan, Mohamed El. 19 March 2012. 'Art Conquers Walls in Cairo'. Foreign Policy Magazine. Online Source: http://foreignpolicy.com/2012/03/19/art-conquers-walls-in-cairo/ Accessed 7 May 2017.

Daskalaki, Maria and Mould, Oli. 2013. 'Beyond Urban Subcultures: Urban Subversions as Rhizomatic Social Formations'. International Journal of Urban and Regional Research, Vol.31 No.1: 1-18.

Elias, Chad. 2014. 'Graffiti, Social Media and the Public Life of Images in the Egyptian Revolution'. In Hamdy, Basma, and Karl, Don eds., Walls of Freedom: Street Art of the Egyptian Revolution, pp.89-91. Berlin: From Here to Fame Publishing.

Ferrell, Jeff. 1995. 'Urban Graffiti: Crime, Control, and Resistance'. Youth \& Society, Vol.27 No.1: 73-92.

Fleming, Juliet. 2001. Graffiti and the Writing Arts of Early Modern England. London: Reaktion Books.

Frederick, Ursula K. 2009. 'Revolution is the New Black: Graffiti/Art and Mark-making Practices'. Archaeologies: Journal of the World Archaeological Congress, Vol.5, No.: 210-237.

Graham, Stephen. 2011. Cities Under Siege: The New Military Urbanism. London and New York: Verso.

Graham-Harrison, Emma. 3 March 2017. "Worst view in the world": Banksy opens hotel overlooking Bethlehem wall'. The Guardian. Online Source:

https://www.theguardian.com/world/2017/mar/o3/banksy-opens-bethlehem-barrier-wall-hotel Accessed 9 May 2017.

Gröndahl, Mia. 2013. Revolution Graffiti: Street Art of the New Egypt. London: Thames \& Hudson.

Hamdy, Basma, and Karl, Don eds. 2014. Walls of Freedom: Street Art of the Egyptian Revolution. Berlin: From Here to Fame Publishing.

Harvey, David. 2012. Rebel Cities: From the Right to the City to the Urban Revolution. London: Verso.

Hassan, Ahmed Aboul, 'The Wall: People's Chronicle and Voice of the Revolution'. In Hamdy, Basma, and Karl, Don eds. Walls of Freedom: Street Art of the Egyptian Revolution, pp.134-135. Berlin: From Here to Fame Publishing.

'Homelessness and Poverty Behind Street Art in London'. 2011. Huffington Post. 13th February. Online Source: http://www.huffingtonpost.com/2011/o2/11/homelessness-and-poverty-_n_822042.html Accessed 8 May 2017.

Kingsley, Patrick. 28 March 2013. 'Closed Off in Cairo: Walls Erected During Egypt Protests Still Standing'. The Guardian. Online Source: https://www.theguardian.com/world/2013/mar/28/egypt-cairo-protestwalls-stil-standing Accessed 8 May 2017.

Lennon, John. 2014. 'Assembling a Revolution: Graffiti, Cairo and the Arab Spring'. Cultural Studies Review, Vol.20, No.1: 237-75.

Macdonald, Nancy. 2002. The Graffiti Subculture: Youth, Masculinity and Identity in London and New York. New York: Palgrave Macmillan. 
Marche, Guillaume. 2012. 'Expressivism and Resistance: Graffiti as an Infrapolitical Form of Protest Against the War On Terror'. Revue française d'études américaines, No.131: 78-96.

Merrifield, Andy. 2014. The New Urban Question. London: PlutoPress.

Minton, Anna. 2012. Ground Control: Fear and Happiness in the Twenty-First-Century City. London: Allen Lane, Penguin Books.

Morayef, Soraya. 22 March 2012. 'The Seven Wonders of the Revolution'. Jadaliyya. Online Source: http://www.jadaliyya.com/pages/index/4776/the-seven-wonders-of-the-revolution Accessed 11 May 2017.

Motumi, Mpiletso. 2012. 'Ruth First mural makes an instant tourist attraction'. The Star. 3rd October. http://www.iol.co.za/the-star/ruth-first-mural-makes-an-instant-tourist-attraction1.1394946\#.VRVgKxeImR8.

Nassar, Tamara. 6 March 2017. 'Banksy's 'Walled Off Hotel' is a form of gentrification'. Mondoweiss: News $\mathcal{E}$ Opinion About Palestine, Israel E the United States. Online Source: http://mondoweiss.net/2017/o3/banksys-walled-gentrification/ Accessed 9 May 2017.

Parry, William. 2011. Against the Wall: The Art of Resistance in Palestine. Illinois: Lawrence Hill Books.

Rahman, Shafiur. 'Street Art Collides With Reality In London'. Openfilm. Online Source: http://www.openfilm.com/videos/street-art-collides-with-reality-in-london Accessed 27th March 2015.

Ross, Kristin. 2015. Communal Luxury: The Political Imaginary of the Paris Commune. London ad New York: Verso.

Sassen, Saskia. 2004. 'Local Actors in Global Politics'. Current Sociology, Vol.52, No.4: 649-670.

——2011. 'The Global Street: Making the Political'. Globalisations, Vol.8, No.5: 573-579.

Stewart, Michelle, and Kortright, Chris. 2015. 'Cracks and Contestation: Toward an Ecology of Graffiti and Abatement'. Visual Anthropology, 28:1: 67-87.

Dominic Davies is a British Academy Postdoctoral Fellow at the English Faculty, University of Oxford, where he also completed his DPhil in March 2015. He has written and published a number of articles and chapters and is the co-editor of two forthcoming essay collections, Fighting Words: Fifteen Books That Shaped the Postcolonial World (Peter Lang, 2017) and Planned Violence: Post/Colonial Urban Infrastructures and Literature (Palgrave, 2018). His first monograph, Imperial Infrastructure and Spatial Resistance in Colonial Literature, 1880-1930, was published by Peter Lang in 2017. He was the Facilitator of the Leverhulme-funded Network, 'Planned Violence: Post/colonial Urban Infrastructures and Literature', and his current research project, Urban Comix: Collaboration, Reconstruction and Resistance in the Divided City, focuses on the way urban space in postcolonial cities is represented in graphic novels, comics and other visual cultures. He is the project facilitator for the British Council-US funded network, 'Divided Cities: Culture, Infrastructure and the Urban Future', and the convener of the network and seminar series. 'Comics and Graphic Novels: The Politics of Form', both based at The Oxford Research Centre in the Humanities (TORCH), University of Oxford. 